Pakistan Journal of Humanities and Social Sciences

January - March 2019, Volume 7, No. 1, Pages 77 - 91

\title{
Manufacturing sector in Pakistan: A Comprehensive Review for the Future Growth and Development
}

Saif ur Rahman ${ }^{1}$, Nor'Aznin Abu Bakar ${ }^{2}$

${ }^{1} \mathrm{PhD}$ Scholar, School of Economics, Finance and Banking (SEFB), College of Business (COB), Universiti Utara Malaysia.

${ }^{2}$ Associate Professor, School of Economics, Finance and Banking (SEFB), College of Business (COB), Universiti Utara Malaysia.

Email: saifrao12@gmail.com

\begin{abstract}
The key objective of the present study is to provide a comprehensive review of the manufacturing sector and its growth from the context of Pakistan. For this purpose, decent review of existing literature with the industrial output is provided while taking some other regions as well. Review of the empirical findings of existing literature and industrial output explains that there is a great need of sectoral growth in Pakistan in present time. The country is facing various issues like higher inflation, low employment opportunities, declining foreign investment and very little focus on economic growth. For the long run financial stability in the economy, significant policy development and implication is a need of time through which more economic development and growth can be achieved. However, a key limitation of the study is not contributing in an empirical context regarding the economic growth, manufacturing sector and its present contribution while taking the economic indicators like GDP, export and import etc. Originality/value of the study can be viewed through its contribution in existing literature while considering the manufacturing sector which is not very well addressed in the earlier literature.
\end{abstract}

Keywords: Manufacturing Sector, Pakistan, Economic Growth and Development, GDP.

\section{Introduction}

For the economic growth, industrialization is considered as the most significant engine in the economy. Various factors can be considered to reflect the attributes of the manufacturing sector in the economy which are under the title of economies of scale, rapid growth in the technology, easy access to global production networks and many others as explained by (Lavopa \& Szirmai, 2012, 2014; Szirmai, 2012; Szirmai \& Verspagen, 2015). In addition, it is also expressed that for the economic development, the transformation from agriculture to manufacturing sector and from manufacturing to service sector is very much 
important (Clark 1941; Kuznets 1957; Chenery 1979; Fuchs 1980). Therefore, the idea that no country can get the economic growth without consideration of economic development is very much common in the existing body of literature. The process of economic growth can be reflected through industrialization and with employment opportunities, there will be a higher level of development in the country as defined by (Levine, 1999; Thirlwall, 1983; Van den Berg, 2016).

With the changes in phases from one sector to any other, the share of manufacturing sector will also be changed. After entering to middle-income classes, it is empirically found that the share of the manufacturing sector is shifted from $20 \%$ to $35 \%$ in the overall economy. After serving to middle-income economies, various states are shifting towards the service sector as in developing economies like Pakistan, the labour force is a major work force available specifically for the manufacturing sector. Meanwhile, the share of employment in the manufacturing sector of Pakistan is $15.30 \%$ while the same level in the agriculture and service is $49.70 \%$ and $28.70 \%$ respectively as per the findings of (Ministry of Finance, 2017).

For the growth of the manufacturing sector, there is a significant need for capital investment from both the local market and from international investors as well. due to fiscal deficit in the poor economies where Government cannot significantly support their various projects, it is very much difficult to support the manufacturing sector as well. so, for the establishment of the manufacturing sector, there is a great need for local and foreign investment for the economic growth (Ministry of Finance, 2017). For the economic growth, the manufacturing sector plays their crucial role in the economy of Pakistan as well. It is known as the third largest sector in Pakistan after the agriculture and service sector and share of this sector is 14 to $16 \%$ per annum of overall GDP in the country. while the contribution in the GDP by service sector is $51 \%$ and for the agriculture sector, this rate is 20 to $21 \%$ as well. in addition, the growth rate for the manufacturing sector in Pakistan is recorded as Rs 158 billion with the $100 \%$ value addition policy as well (Ministry of Finance, 2017).

As per the review of the performance of manufacturing sector in Pakistan, it is found that this sector has followed a trend of the boom-bust cycle as compared to other economies like China, India, Russia and South Africa who have been succeeded in creating a diversification in the manufacturing sector. This sector is trying to grow in the country with the sustainable position as various problems have been experienced in the country. These problems include the low production capacity of the local firms, lack of innovative ideas and 
products, with the traditional way of manufacturing as well (Agenor, Canuto, \& Jelenic, 2012; Kalim, 2001; Mangla \& Din, 2015; Ul Haque, 2007). The problem is that over the last server years, the performance through various economic indicators is showing very poor outcomes in financial terms. In the financial year 2015, it is found that economic goals like GDP growth, production of electricity, federal revenue enchantment, lowering the value of circular debt in the economy are in a very miserable position. Besides, the manufacturing sector in the country is lacking diversification, lower production capacity and the addition of total value in the economy.

It is also expressed in earlier studies that lack of good performance in the manufacturing sector is due to the lack of concentration on the various types of industrial products, low quality, very low exposure of foreign markets, and no proper competitive position as well. besides, low or little focus on the intellectual capital for the human development, lack of research and development as some of the other problems creating a financial trouble for this sector at present time (Barro, 1991; Hartwell, 2017; Kalim, 2001; Lewis, 2013).

Figure 1 explains the output regarding the value added by the various industry in Pakistan since 1960 to 2017 as a \% of GDP. It is found that the highest value added by all the industries was 25.53 during the year 2005 in the last decade. However, after that year there is a gradual decline in this contribution by all the industries and in the present year 2017, this value is recorded at 17.94 the same which was back in the year 1967 and 1968 respectively. This present declining trend is providing enough evidence which explains that significant attention is required for the improvement of overall contribution by the industries regarding value addition in GDP.

Figure 1: Industry, Value Added (\% of GDP)

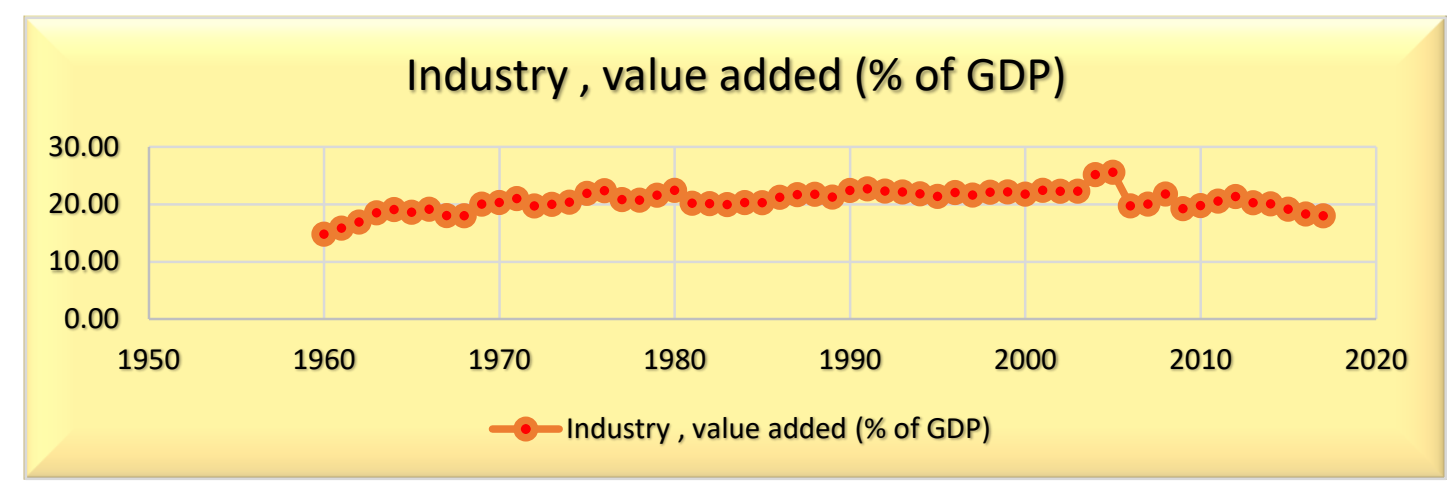

Source: Data from WDI, calculation based on authors findings 
Figure 2 explains the outcome regarding the value added by the manufacturing sector in Pakistan from 1960 to 2017. Here the manufacturing industries cover the title under ISIC list as developed by world bank group from 15-37 list. The portion of value added is created after adding the output in aggregate after subtracting the amount of intermediate input as defined by WDI. However, the value of depreciation is not under consideration while calculating its value. In Pakistan, as expressed in figure 2, the value added by manufacturing is now at the lowest stage which is 11.98, the same which was in the year 1962 and lower than the 1960s. This indicates that the manufacturing sector is facing serious trouble and needs significant attention by the Government for the further improvement.

Figure 2: Manufacturing value added (\% of GDP)

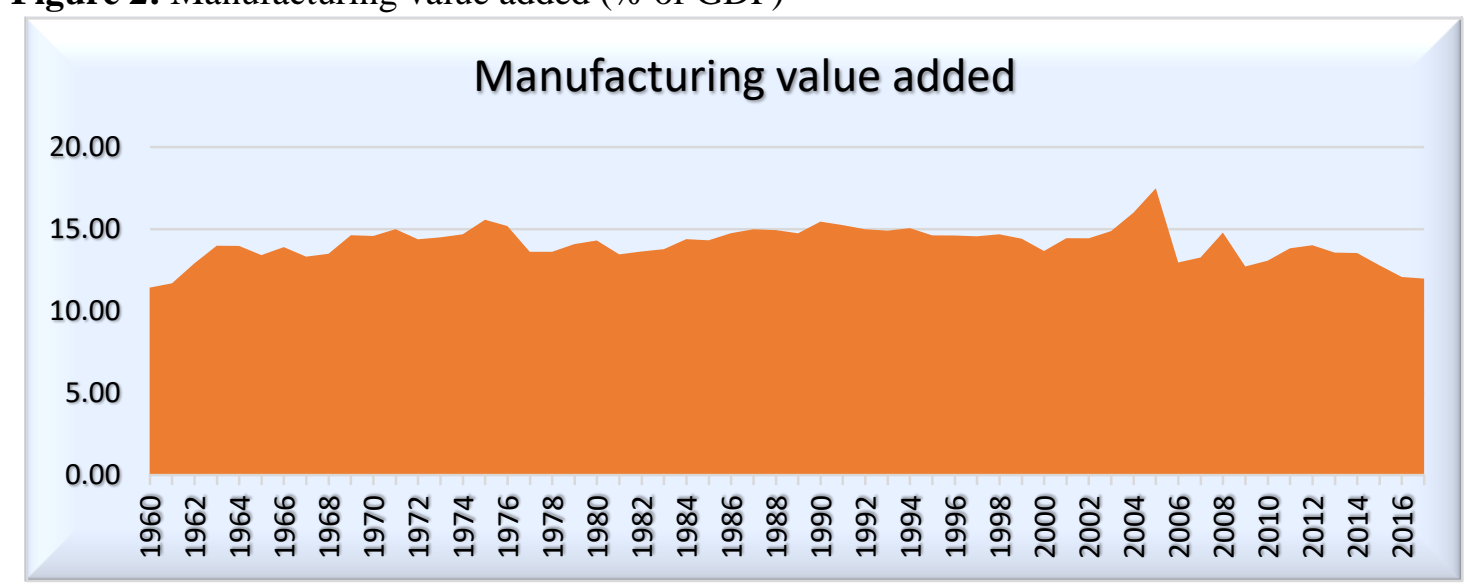

Source: Data from WDI, calculation based on authors findings

\section{A. Manufacturing Sector of Pakistan: A Historical Perspective}

The economic significance of the manufacturing sector in any economy cannot be overemphasized, especially in a broader picture of globalization in which exports play a pivotal role in backing the country's economic profile in the world. The manufacturing sector has long been a key pillar of the Pakistan economy. The manufacturing sector of Pakistan constitute engineering industry, textile industry, chemical industry, agro-based industry, and SMEs. This sector is considered the second largest sector of the economy as it contributes to Pakistan's GDP by 12.80 per cent (World Development Indicators, 2017). In addition, the manufacturing exports of Pakistan are 78.23 per cent of total merchandise exports. Similarly, the share of manufacturing (industry) employment as a percentage of total employment is 19.8 per cent as per modelled (International Labour Organization) ILO estimates (World Development Indicators, 2017). Pakistan's manufacturing sector is primarily characterized by large-scale firms as these firms constitute for almost 80 per cent of the industry, however, the 
share of small-scale manufacturing remained minimal and remained around 13.7 percent of the industry (Ministry of Finance, 2017).

Figure 3: Growth of Manufacturing

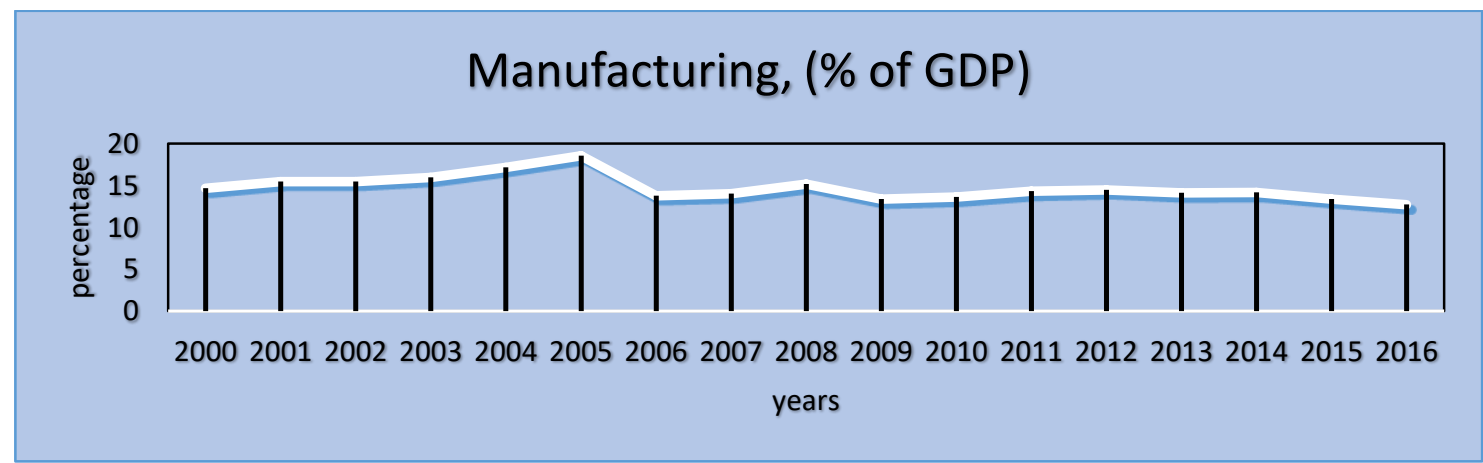

Source: World Development Indicator 2016

As shown in Figure 3, the Pakistan Manufacturing Sector growth (\% of GDP) over the years has witnessed a series of ups and down. In 2000-2016, manufacturing value addition a steady rise, but this was ephemeral, as it declined again in 2005, a steady decline was observed from 2012-2016. It is clearly seen from the graph that value addition as a percentage of GDP in Pakistan is not very encouraging. The decreasing trend from the last six years depicts that it should be checked that why it is not increasing. In a country like Pakistan, the industrial sector consists of large, medium and small-scale organizations while the industrial sector has significant importance for the economic development as well. Historically it is found that those countries have strong industrial sector can get more economic growth and development over a longer period.

However, in a country like Pakistan poor performance of the manufacturing sector has created various issues and made the economy with the poor output. However, after the detailed review of the historical trend of growth of manufacturing sector in Pakistan, it is found that growth in the 1950s of this sector was $10.37 \%$ for the $5.04 \%$ for large-scale industries and 5.34 for the small-scale industries as well. Table 1 express the outcome of the development of the manufacturing sector in Pakistan with reference to the large-scale industry. However, for the good growth structure, the need for well and clear policies for the fostering of small and medium scale industries are very much significant (Chaudhry \& Andaman, 2014). 
Table 1: Share of the Manufacturing sector in GDP (\%)

\begin{tabular}{|c|c|c|c|c|c|c|}
\hline Period & \multicolumn{2}{|c|}{ Percentage share in GDP } & \multicolumn{3}{c|}{ Real growth rate } \\
\hline & $\begin{array}{c}\text { Total } \\
\text { manuf. }\end{array}$ & $\begin{array}{c}\text { Large- } \\
\text { scale }\end{array}$ & $\begin{array}{c}\text { Small- } \\
\text { scale }\end{array}$ & $\begin{array}{c}\text { Total } \\
\text { manuf. }\end{array}$ & $\begin{array}{c}\text { Large- } \\
\text { scale }\end{array}$ & $\begin{array}{c}\text { Small- } \\
\text { scale }\end{array}$ \\
\hline 1950 & 10.37 & 5.04 & 5.34 & 7.76 & 15.75 & 3.30 \\
\hline 1960 & 14.91 & 10.65 & 4.26 & 9.93 & 13.39 & 2.91 \\
\hline 1970 & 16.52 & 12.33 & 4.19 & 5.50 & 4.84 & 7.63 \\
\hline 1980 & 16.65 & 12.26 & 4.38 & 8.21 & 8.16 & 8.40 \\
\hline 1990 & 17.18 & 12.15 & 5.02 & 3.89 & 3.54 & 4.87 \\
\hline 2000 & 17.47 & 11.85 & 5.62 & 7.34 & 7.70 & 7.69 \\
\hline $1950-$ & 15.43 & 10.62 & 4.81 & 7.11 & 8.90 & 5.63 \\
2016 & & & & & & \\
\hline
\end{tabular}

Source: SBP annual report 2014-16

The findings in table 1 express some meaningful discussions. On average the performance of the sector seems to be a little bit impressive. It is found that during 1950 to 2015, the growth of manufacturing sector is recorded at 7.11 expect during the year 1970 and 1990 as well. The reason is that during this time duration, the sector growth is assumed at $8 \%$ on average and various industries grew at the rate of $7.7 \%$ approximately. The reason behind this growth is linked with the industrial policies, focusing on the consumer goods and domestic raw material used as well.

However, during the time of the 1960s, the growth of manufacturing sector is recorded at $9.9 \%$ with the number of imitative which has created a good trend for the smooth growth. These include the import policy of the raw material, export subsidies, bonus schemes and rebate on the tax rates as well. besides, the benefits like accelerated depreciation allowances were also granted to various investors to boost the investment to the economy. Meanwhile, during the time period of the 1970s, the growth of the manufacturing sector has been declined significantly and came to the level of $5.5 \%$. The reason behind this decline is the various nationalization policies declared by the Government on that time. In the same duration, various sectors like cement, oil refining, chemical and some others are transformed to the public sector with fixing the prices as well.

During the time of the 1980s, it is found that various controlled polices and rules have been implemented by the Government to boost the economy. An overall process of economic recovery under the title of denationalization has been started which have resolved the various tax conflicts in the economy. Administrative controls have provided a path towards the speedy recovery of economic activities with no investment licensing requirements. These policies have helped the growth of the economy up to 8.21 during this time. 
Although, the idea of deregulation continues to 1990 s, the slow industrial growth has been experienced during this time with a rate of $3.9 \%$ as well. A various number of factors are assumed to be responsible for this issue which includes the depressed growth of industrial sector, political instability, numerous economic bottlenecks. At the same time, a sharp increase in the prices of various products has also been experienced in the economy.

However, the manufacturing sector remained the momentum during the time period of 2000 with the average growth rate of $7.3 \%$. This growth rate is experienced from both small and large-scale manufacturing sector firms. In the present year, financial outcome of the manufacturing sector is not very good and there is a significant decline in the productivity because of poor domestic security, decline in the FDI as well.

Figure 4 Growth of Large Scale Manufacturing

\section{Large scale ,Percentage share of Manufacturing in GDP}

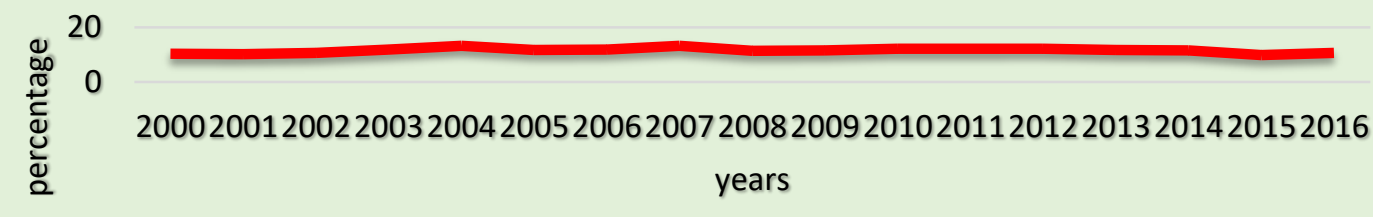

Source: World Development Indicator 2016

Figure 4 presents the percentage share of large-scale manufacturing as a share of GDP. The graph shows that the increasing trend of share in GDP since 2008 while it shows a decreasing trend since 2013 and increasing again in 2015. While considering the significance of FDI, the effect of globalization on a country like Pakistan cannot be ignored. Meanwhile, over the last two decades, slow growth in the manufacturing sector is experienced as the rate of growth during 2015 is just $4 \%$ as compared to last year. due to low tax collection, and little public and private investment with the decline in the value of exports as well. To keep the foreign reserve at a reasonable level, Government has to take the obligation for the sustainable cost, and high growth in the economy during the financial year 2018.

Although, the growth in the industry is seems to be reasonable in the coming years, the comparison with other states explains the fact that slow trend is recorded in the South Asian economies. The manufacturing sector in Pakistan is facing the myriad constraints, low development of human and related capital, poor physical and infrastructure. It is found that more than 37.8 of industrial value has been added from eh sector like food and textile alone. 
While very little contribution from the rest of the sectors is experienced. In addition, those industries which are based on the raw materials from the indigenous items are an accountant for $60 \%$ value addition, meanwhile, only $15 \%$ is contributed from the electoral and nonelectrical machinery and heavy equipment as well.

As per the contribution of $13.5 \%$ in the overall economy, the manufacturing sector is assumed to be the second largest sector in the economy and employing a major portion of the workforce as well. It covers the large-scale manufacturing industry with $80 \%$ share in GDP, while small-scale contribution is $1.8 \%$ and finally the third component which accounts for .9 $\%$ in overall GDP of the country. during the present time, the growth of the manufacturing sector is assumed to be very much consistent. During Fiscal Year 2017, it recorded an impressive growth of 5.3 percent against 3.7 percent of last year which helped the overall industrial sector to improve by 5.0 percent against 5.8 percent last year.

Figure 5: Growth of Small Scale Manufacturing

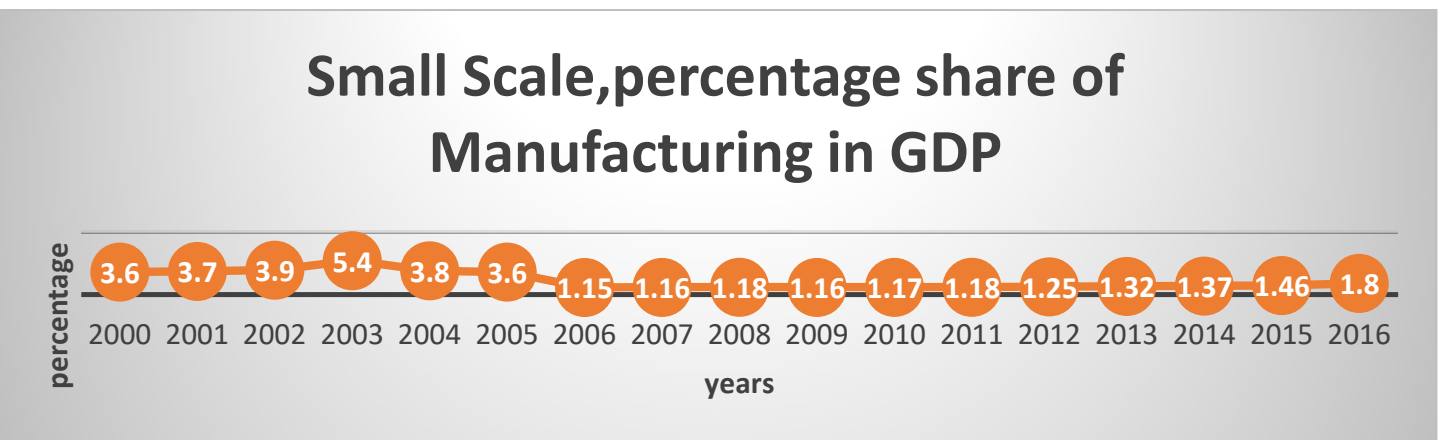

The graph 5 shows small-scale manufacturing as a percentage of GDP in Pakistan. The graph shows a smooth trend since 2006 and an increasing trend in 2013 and onward. Small-scale production has also important due to its increasing trend as percentage share in GDP of Pakistan.

In the year 2011, the industrial sector in Pakistan has contributed $25 \%$ in GDP and the contribution by the manufacturing sector in the same year is assumed to be 14.54 of GDP as per the findings of world bank in the same time. although during the start of last decade, a decline in GDP is experienced which remains until the global financial crisis in the year 2008. It is also found that overall $20 \%$ labour force has been captured by the same sector as per the findings of (Government of Pakistan Ministry of Finance, 2012).

\section{Theoretical Review: Manufacturing Sector and growth}

For the overall economy, the manufacturing sector plays a significant role specifically in the developing countries. With the increase in the investment from the investors, 
manufacturing products increase as well, and such investment leads to the level of economic growth (Schauer et al., 2017). As per the findings of the manufacturing sector act as an engine in the growth of developing economies with the two major reasons. The first is that scope of learning and productivity will be larger and the rate of productivity and growth for the manufacturing will positive dependency on the growth rate of output in the manufacturing as well. at second, the manufacturing sector of the economy can increase the growth productivity due to its link with the other non-manufacturing sector. It also focuses on the human capital which at the end discretionary expenditure in the overall economy and provides benefit to other sectors as well.

In the earlier studies, it is found that there exists a significant correlation between the level of per capita income and degree of industrialization in the developing economies. The reason is that higher value of industrialization leads to the higher economic growth in the country. besides, while doing this activity, people in the economy can get the job opportunities with the increasing value of per capita income as well (Kaldor, 1966, 1967; Rodrik, 2009). Meanwhile, it is empirically found that there exists a spillover effect for the manufacturing sector in various economies (Szirmai \& Verspagen, 2015).

In addition, various studies have provided the evidence that economies become rich with the significant share from manufacturing sector almost 20-35\% of GDP. Beyond this point, there is a significant shift in the consumption pattern, hence the job creation increases in the economy and GDP beings to fall with the U-shaped curve. The reason is that over long run industrialization requires a significant amount of money but because of the economic problem, countries like Pakistan cannot contribute the amount of money with the required level. They are in constant need of foreign capital in forms of both direct and indirect investments.

Besides, the possible explanation for the empirical findings is that the economic growth and key sources are very much different for both the developing and developed economies. The factor for the economic growth in the developed economy can be expressed as the knowledge-based and innovation as well. It is also found that increased in the industrial growth of developing economies depends upon the shifting of technology from developed economies with significant ideas as well.

During this time, the adoption of technology from developed to developing economies assumes to a significant role player, however, this trend is assumed to be distinct in various countries as well. for instance, have found that the tradable manufacturing sector 
for the developing economies is assumed a major tool to get the knowledge and innovative ideas in the economy. In addition, various studies have also put their focus on the learning, adoption and implementation of advanced technologies with the investment as compared to merely focusing on the consumption as well (Boucekkine, Del Rio, \& Licandro, 2003). So, a higher level of capital is called for the investment from manufacturing sector which is crucial for the middle-income economies. Moreover, according to Barro (2001), if a country has better institutions and higher human capital level, investors can better introduce advanced technologies for domestic firms. As a consequence, in contrast to other sectors, the manufacturing sector, where technology transfer mainly takes place, can better utilize domestic human capital and economic institutions (Piore \& Sabel, 1984).

The study of (Mahmood \& Siddiqui, 2000) expressed the TFP for the manufacturing sector in Pakistan during the time duration of 1972 to 1997. They have explained that country has experienced an increased in the expenditure on research and development, scientific growth, technical manpower and investment on human capital has its significant and positive influence on the growth of the manufacturing sector. Besides, it is found that both the knowledge and level of human capital are explaining 18 and $30 \%$ variation in TFP with the positive influence of trade openness on the value of manufacturing sector growth.

The study of (Aqeel \& Butt, 2001) analyzed the association between the manufacturing output and economic performance from the perspective of Kaldorian first and $2^{\text {nd }}$ growth late while taking the sample of Latin American states. The time of the study was 1985 to 2001 with the findings that there exists a significant and positive association between the industrial growth and level of overall productivity in the economy. It is also found that for the economic growth, the manufacturing sector is an engine in the economy with the significant growth rate in the Latin America through the manufacturing sector.

Research contribution by (Anowor, Ukweni, Ibiam, \& Ezekwem, 2013) explains that there exists a significant association between the foreign direct investment and Nigerian manufacturing sector while applying the ordinary least squares approach. Although, Nigeria is currently a developing nation positive association between the FDI and manufacturing sector growth is very much significant for the further success of the country. It is suggested that more focus on macroeconomic policies and procedures will lead to better economic health and overall growth in the economy.

Shahbaz, Loganathan, Zeshan, and Zaman (2015) explored the manufacturing sector of Pakistan during the time of 1972 to 2003 while considering the cost competitiveness. 
However, the key point to discuss is that data related to the cost of the manufacturing sector is not very well organized after 1995 and for this purpose, composite price index has been compared with the export prices. It is found that both the composite price index and nonfactor price output index are growing at the faster rate during the sample period. In addition, prices of energy in the economy, imported machinery, and wage rates are defining the higher level of inflation in the economy.

Ahmad, Afzal, and Ghani (2016) estimated the total factor productivity for the largescale manufacturing sector during the time of 1975 to 2001 with three diversified techniques. The first approach has considered the classical model with its comparison to four other models. The application of simultaneous equation method is very much significant for the productivity of large-scale manufacturing industry. Overall findings explain that productivity of the sector is influenced by the capital, labour, national product per capita income as well. In addition, study findings are very much useful while developing strategic planning for the country over the long run.

The study of Mirza and Kanwal (2017) examined the efficiency of large-scale manufacturing sector in Pakistan while applying the stochastic production frontier method during the time period of 1995 to 2001 while taking a sample of 101 industries. Findings of the study expressed that there is a great need of improvement in efficiency of large-scale manufacturing sector. However, after applying the disaggregate analysis, a study has provided mixed output. At first, some industries are showing deterioration in their efficiency while some are not.

Zaidi (2005) examined the association between the growth of GDP per capita and value-added share of the manufacturing sector while applying the fixed and random effect. Besides, Hausman test is also applied for the sample of 92 countries while dividing the time span in 1950 to $1970,1970-1990$ and finally 1990 to 2005. Findings of the stated time were compare with the service sector over the same sample of the study. They have found that for the economic growth manufacturing sector is playing its role as an engine in the economy with the other development like education and health as well. meanwhile, it is also found that there is a positive impact of the manufacturing sector on the growth of the economy.

Mangla and Din (2015) analyzed the empirical impact of various macroeconomic and environmental indicators on the growth of the manufacturing sector in Pakistan while taking the fiscal and monetary policy under their observation. It is expressed that over the last two decades, the situation of Pakistan regarding the macroeconomic is imbalanced which has 
finally led to the financial instability over time. although some macroeconomic changes have been implemented with the trade account deficit and low foreign remittance. But it was imperative to think about the result of leverage on the overall economic growth in the country.

Anyanwu and Yameogo (2015) explained the association between the FDI and its impact on economic growth while taking the agriculture, manufacturing, mining and telecommunication as a key sector of study during the time of 1980 to 2011. The application of economic tools explains that in a long time, the agriculture sector with the manufacturing has their negative influence on the growth of the economy. Meanwhile, results indicate that mining and telecommunication have shown a positive influence on the economic growth. however, in the short run, FDI has no significant association with the agriculture sector while taking the impact of the manufacturing sector as negative. Besides, they have recommended that level of government, public and private sector have their significant influence overgrowth in the economy.

Ahmed, Shahbaz, Qasim, and Long (2015) examined a relationship among agriculture, manufacturing, services sectors, and Gross Domestic Product (GDP) growth in Pakistan. To explore this relationship, Time Series data has been taken for the period of 1989 to 2012. This study employed the Econometrics technique to investigate a relationship between sector shares and economic growth. To select the best technique, Vector Error Correction Model (VECM) was applied. Wald Test was used to check the short run Causality among variables (i.e., agriculture, manufacturing, services, and GDP). VECM confirmed that there was a long run Causality from agriculture, manufacturing, and services sectors to GDP in Pakistan. There was a short run Causality from manufacturing and services sectors to GDP and the same applies for GDP to agriculture and manufacturing sectors. But there was unidirectional Causality from the manufacturing sector to GDP and from services sector to the agriculture sector. They found of the study exhibit that GDP will be positively influenced due to increasing in agricultural and manufacturing, whereas the services sector does not influence GDP but GDP influences services sector in Pakistan.

In recent year, the study of (Umoh, Jacob, \& Chuku, 2012) expressed the impact of FDI on the performance of the industrial sector and growth in the economy of Nigeria. While applying the time series analysis during the time of 1981-2015, it is found that GDP is very much sensitive to the value of FDI in the economy while taking the impulse response function along variance decomposition method. In addition, the application of VDC and VAR with co- 
Pakistan Journal of Humanities and Social Sciences, 7(1), 2019

integration explains that there exists a bidirectional association between the FDI and industrial output in the selected economy.

\section{Conclusion and Recommendations}

The manufacturing sector in Pakistan is facing the situation of boom-bust because of the deficit in the public financing and various external accounts. This situation has created some serious issues for the economic growth while leaving very little growth momentum. In addition, the country is also facing a fiscal deficit and a higher level of inflation in the recent time which create macroeconomic instability and exchange rate volatility. The outcome of the macroeconomic stability index reveals the fact that during the period of 2000 to onward country remained unstable because of higher inflation and other economic issues. because of the slow-growing economy, the outcome for the country over the last 20 years remains very much crucial resulted in macroeconomic imbalances with the hampering of private investment in the manufacturing sector as well. Meanwhile, various macroeconomic policies which are applied to stabilize the economy are not providing well output due to the lack of integration between the departments and various industries as well.

As per the policy recommendation, it is suggested that country management must consider the macroeconomic priorities with the framework of monetary and fiscal guidelines. Under global competition, Pakistan must focus on the niche sector specifically for the small and medium enterprises which in return can provide the real growth in the economic output, employment opportunities, increasing living standards and exports as well. In addition, SMEs are playing their significant role while increasing the value of exports in the country in various cities like Karachi, Lahore, Sialkot, Gujrat, Gujranwala are under consideration. Besides, Rashid and Burki (2013) cotton are experienced as the potential driver for the creation of higher values of exports in the country.

For the overall economy, the following outlines can also provide some meaningful guidelines

i. significant attention is required towards the macroeconomic imbalance for the structural and overall improvement in the country.

ii. To avoid the economic downturn, strong policies are very much needed which help in a significant way for the improvement of the economic situation.

iii. Political stability is playing a key role in the economy. Therefore, it is recommended that a higher level of governance is required for the improved business performances and financial stability.

iv. Situation of law and order is also among the fundamental factors to play their role for the economic prosperity. So, it is also recommended that the country administration should also focus on this issue. 


\section{References}

Agenor, P., Canuto, O., \& Jelenic, M. (2012). Avoiding Middle Income Growth Traps, The World Bank. Policy Research Working Paper, 6210.

Ahmad, D., Afzal, M., \& Ghani, U. (2016). Impact of Monetary Policy on Economic Growth Empirical Evidence of Pakistan. International Journal of Applied, 4(6).

Ahmed, K., Shahbaz, M., Qasim, A., \& Long, W. (2015). The linkages between deforestation, energy and growth for environmental degradation in Pakistan. Ecological Indicators, 49, 95-103.

Anowor, O. F., Ukweni, N. O., Ibiam, F., \& Ezekwem, O. S. (2013). Foreign direct investment and manufacturing sector growth in Nigeria. International Journal of Advanced Scientific and Technical Research, 3(5), 231-254.

Anyanwu, J. C., \& Yameogo, N. D. (2015). What drives foreign direct investments into West Africa? An empirical investigation. African Development Review, 27(3), 199-215.

Aqeel, A., \& Butt, M. S. (2001). The relationship between energy consumption and economic growth in Pakistan. Asia-Pacific Development Journal, 8(2), 101-110.

Barro, R. J. (1991). Economic growth in a cross section of countries. The quarterly journal of economics, 106(2), 407-443.

Boucekkine, R., Del Rio, F., \& Licandro, O. (2003). Embodied Technological Change, Learning-by-doing and the Productivity Slowdown. Scandinavian Journal of Economics, 105(1), 87-98.

Hartwell, R. M. (2017). The industrial revolution and economic growth: Routledge.

Kalim, R. (2001). A Measure of the Elasticity of Substitution in the Manufacturing Sector of Pakistan.

Lavopa, A., \& Szirmai, A. (2012). Industrialization, employment and poverty.

Lavopa, A., \& Szirmai, A. (2014). Structural modernization and development traps: an empirical approach.

Levine, R. (1999). Financial development and economic growth: views and agenda: The World Bank.

Lewis, W. A. (2013). Theory of economic growth: Routledge.

Mahmood, Z., \& Siddiqui, R. (2000). State of technology and productivity in Pakistan's manufacturing industries: Some strategic directions to build technological competence. The Pakistan Development Review, 1-21.

Mangla, I. U., \& Din, M. (2015). The Impact of the Macroeconomic Environment on Pakistan's Manufacturing Sector.

Ministry of Finance. (2017). Economic Survey of Pakistan. from MOF http://www.finance.gov.pk/survey/chapters_17/pakistan_es_2016_17_pdf.pdf

Mirza, F. M., \& Kanwal, A. (2017). Energy consumption, carbon emissions and economic growth in Pakistan: Dynamic causality analysis. Renewable and Sustainable Energy Reviews, 72, 1233-1240.

Piore, M. J., \& Sabel, C. F. (1984). The second industrial divide: possibilities for prosperity (Vol. 4): Basic books New York.

Schauer, P. R., Bhatt, D. L., Kirwan, J. P., Wolski, K., Aminian, A., Brethauer, S. A., . . Nissen, S. E. (2017). Bariatric surgery versus intensive medical therapy for diabetes - 5-year outcomes. New England Journal of Medicine, 376(7), 641-651.

Shahbaz, M., Loganathan, N., Zeshan, M., \& Zaman, K. (2015). Does renewable energy consumption add in economic growth? An application of auto-regressive distributed lag model in Pakistan. Renewable and Sustainable Energy Reviews, 44, 576-585. 
Szirmai, A. (2012). Industrialisation as an engine of growth in developing countries, 19502005. Structural change and economic dynamics, 23(4), 406-420.

Szirmai, A., \& Verspagen, B. (2015). Manufacturing and economic growth in developing countries, 1950-2005. Structural change and economic dynamics, 34, 46-59.

Thirlwall, A. P. (1983). A plain man's guide to Kaldor's growth laws. Journal of Post Keynesian Economics, 5(3), 345-358.

Ul Haque, I. (2007). Rethinking industrial policy: United Nations Conference on Trade and Development.

Umoh, O. J., Jacob, A. O., \& Chuku, C. A. (2012). Foreign direct investment and economic growth in Nigeria: An analysis of the endogenous effects. Current Research Journal of Economic Theory, 4(3), 53-66.

Van den Berg, H. (2016). Economic growth and development: World Scientific Publishing Company.

Zaidi, S. A. (2005). Issues in Pakistan's economy. OUP Catalogue. 